Review article

\title{
Metabolic and endocrine differences between Bos taurus and Bos indicus females that impact the interaction of nutrition with reproduction
}

\author{
Roberto Sartori ${ }^{\mathrm{a}, *}$, Lindsay U. Gimenes ${ }^{\mathrm{b}}$, Pedro L.J. Monteiro Jr ${ }^{\mathrm{a}}$, \\ Leonardo F. Melo ${ }^{\mathrm{a}}$, Pietro S. Baruselli ${ }^{\mathrm{c}}$, Michele R. Bastos ${ }^{\mathrm{d}}$ \\ a Department of Animal Science, University of São Paulo, Piracicaba, São Paulo, Brazil \\ ${ }^{\mathrm{b}}$ Department of Preventive Veterinary Medicine and Animal Reproduction, University of São Paulo State (UNESP), Jaboticabal, São \\ Paulo, Brazil \\ ${ }^{\mathrm{c}}$ Department of Animal Reproduction, University of São Paulo, São Paulo, São Paulo, Brazil \\ d Ourofino Saúde Animal, Cravinhos, São Paulo, Brazil
}

\section{A R T I C L E I N F O}

\section{Article history:}

Received 21 October 2015

Received in revised form 4 January 2016

Accepted 14 March 2016

\section{Keywords:}

Bos taurus

Bos indicus

Hormone

Metabolism

Nutrition

Steroid

\begin{abstract}
A B S T R A C T
During the last decade, researchers have studied the differences in the reproductive physiology between Bos taurus and Bos indicus breeds. This manuscript focuses on the main aspects of ovarian function and circulating hormones of $B$. taurus and $B$. indicus cows and heifers. In general, there is no difference in the number of follicle waves during the estrous cycle, however $B$. indicus have greater antral follicle count, circulating insulin, and insulin-like growth factor 1 (IGF1) than B. taurus. Moreover, despite of $B$. taurus having larger ovulatory follicle diameter and maximum CL volume, they have lesser peak circulating estradiol concentrations and lesser circulating progesterone concentrations than $B$. indicus. We may speculate that there are two main factors related to lesser circulating concentrations of estradiol and progesterone in B. taurus when compared with B. indicus: increased liver metabolism of steroid hormones and lesser production by follicles and CL. Differences between the two genetic groups are also observed with respect to in vitro embryo production because in addition to B. indicus having greater numbers of retrieved oocytes, due to greater antral follicle count, they also have greater percentages of viable oocytes, number of blastocysts, and blastocyst rates when compared with $B$. taurus. Effects of dietary intake on embryo quality may differ between $B$. taurus and $B$. indicus due to different concentrations of circulating insulin and IGF1. For in vivo and in vitro embryo production, an increase in circulating insulin concentrations is negatively associated with oocyte/embryo quality and conception rates. However, this seems to be more pronounced in B. taurus breeds. Differences in ovarian function related or not to nutrition between these two genetic groups are very consistent and may be related to the influence of metabolic hormones such as insulin and IGF1.
\end{abstract}

(c) 2016 Elsevier Inc. All rights reserved.

\section{Introduction}

During the last decade, there were several studies that directly compared ovarian function and circulating

\footnotetext{
* Corresponding author. Tel./fax: +55 1934294134.

E-mail address: robertosartori@usp.br (R. Sartori).
}

hormones of Bos taurus versus Bos indicus cattle under similar management conditions. Because Holstein (B. taurus temperate breed) and Nelore (B. indicus tropical breed) are among the principal dairy and beef cattle breeds, respectively, they are the most representative of the studies discussed in this article. In the following section, we present data of studies that evaluated reproductive function 
and embryo production in B. taurus and B. indicus cows and heifers, showing differences in circulating hormones and metabolites, ovarian morphology and dynamics, as well as in in vivo embryo production and in vitro embryo production (IVEP) between these two subspecies. We also discuss potential different reproductive responses to nutrition that may be influenced by metabolic hormones in $B$. taurus versus $B$. indicus. For all data presented in this manuscript, differences between treatments were considered significant when P value was less than or equal to 0.05 .

\section{Ovarian function in B. taurus versus $B$. indicus}

Although several studies evaluated estrous cycle patterns in B. taurus and B. indicus cattle, very few have directly and simultaneously compared these genetic groups under the same environmental and management conditions. An experiment performed in Florida compared multiparous lactating Angus (temperate B. taurus; $\mathrm{n}=12$ ), Brahman (tropical B. indicus; $\mathrm{n}=12$ ), and Senepol (tropical B. taurus; $\mathrm{n}=12$ ) cows throughout an estrous cycle during the summer [1]. In this study, most Angus and Brahman cows had two follicular waves during the estrous cycle (72.7 and $55.6 \%$, respectively) and $70 \%$ of the cycles of Senepol cows had three waves. A study in our laboratory [2] compared estrous cycle patterns between Nelore $(n=12)$ and Holstein ( $\mathrm{n}=12)$ nonlactating cows kept in individual stalls, receiving a maintenance diet according to the National Research Council (NRC) [3]. After 21 days of adaptation, estrus was synchronized and the cows were monitored daily by ovarian ultrasonography and blood sampling for an interovulatory interval. It was observed that $80 \%$ of Nelore cows and $60 \%$ of Holstein cows had three follicular waves during the estrous cycle. The other cows presented two waves. Moreover, the average length of the estrous cycle was 23 days (ranging from 21 to 26), and it was similar between Nelore and Holsteins. Differences in the antral follicle count (AFC) were observed between Nelore and Holstein cows. At wave emergence, the number of 2 to $5 \mathrm{~mm}$ follicles present in the ovaries was $42.7 \pm 5.9$ (ranging from 25 to 100) in Nelore and $19.7 \pm 3.2$ (ranging from 5 to 40) in Holstein cows. Follicle deviation occurred, on average, 2.3 days after ovulation, independent of breed, when the diameter of the greatest follicle reached $7.0 \pm 0.2$ and $8.9 \pm 0.4 \mathrm{~mm}$ in Nelore and Holstein cows, respectively. The maximum diameter of the ovulatory follicle $(13.4 \pm 0.3$ vs. $15.7 \pm 0.3 \mathrm{~mm}$ ) as well as the corpus luteum (CL) volume $\left(4.9 \pm 0.5\right.$ vs. $\left.7.6 \pm 0.5 \mathrm{~cm}^{3}\right)$ were smaller in $B$. indicus than in $B$. taurus. However, circulating progesterone (P4) concentrations on D7 ( $2.8 \pm 0.2$ vs. $2.0 \pm 0.1 \mathrm{ng} / \mathrm{mL})$ and on D14 $(4.6 \pm 0.4$ vs. $4.1 \pm 0.2 \mathrm{ng} / \mathrm{mL})$ of the estrous cycle and the preovulatory estradiol (E2) peak ( $12.7 \pm 1.0$ vs. $7.7 \pm 0.7 \mathrm{pg} /$ $\mathrm{mL}$ ), as well as preprandial circulating insulin concentrations $(9.9 \pm 1.5$ vs. $3.0 \pm 0.7 \mu \mathrm{IU} / \mathrm{mL})$ were greater in Nelore than in Holstein cows. Furthermore, preprandial circulating insulin concentrations were greater in the follicular phase as compared to the luteal phase in Nelore (11.9 \pm 2.1 vs. $8.3 \pm 1.5 \mu \mathrm{IU} / \mathrm{mL}$ ) as well as in Holstein (4.2 \pm 1.1 vs. $2.2 \pm 0.6 \mu \mathrm{IU} / \mathrm{mL}$ ) cows. Similarly, another study [4] compared the follicle dynamics of Holstein $(\mathrm{n}=15)$ versus Gir ( $B$. indicus tropical breed; $\mathrm{n}=11$ ) heifers kept under the same environmental and nutritional conditions. No difference was found in the interovulatory interval between Holstein and Gir (22.2 \pm 0.7 vs. $22.1 \pm 1.0$ days, respectively). Holstein heifers in relation to Gir heifers had: less follicle waves per cycle ( $2.8 \pm 0.2$ vs. $3.4 \pm 0.24)$, lesser AFC $(27.7 \pm 2.2$ vs. $64.2 \pm 17.1$ follicles $)$, larger ovulatory follicle diameter ( $15.0 \pm 0.4$ vs. $13.7 \pm 0.7 \mathrm{~mm})$, and larger maximum CL diameter ( $26.9 \pm 0.5$ vs. $22.4 \pm 0.8 \mathrm{~mm})$. No differences were found between breeds for the time of deviation. However, Holstein heifers presented larger dominant follicles (DF; $7.9 \pm 0.3$ vs. $6.7 \pm 0.3 \mathrm{~mm}$ ) at deviation when compared with Gir heifers.

Therefore, it was shown that even under similar environmental and nutritional conditions, there are substantial differences in ovarian function and circulating hormones between $B$. indicus and $B$. taurus. These data presented previously are in agreement with other studies that have shown greater AFC in B. indicus cattle [1,5-9], which are associated with greater circulating anti-Mullerian hormone [4,7]. Significant differences in AFC between $B$. indicus and $B$. taurus breeds may be also associated with greater circulating concentrations of insulin and insulinlike growth factor 1 (IGF1) in $B$. indicus cattle $[1,8,10]$. The selection of the DF capable of ovulating among a group of antral follicles is a dynamic process, regulated by interactions between gonadotropins, growth factors, and intraovarian substances [11]. Regarding follicle dynamics at the time of selection of the DF, other studies have also detected smaller follicle sizes when deviation occurs in $B$. indicus cattle (discussed by Sartori et al. [12,13]). For example, in one of the experiments reported by Gimenes et al. [14], 18 cycling Nelore heifers, ranging from ages 20 to 24 months and weighing more than $325 \mathrm{~kg}$, had their ovulation synchronized and were examined by transrectal ultrasonography every 12 hours for 5 days. The growth rate ( $\mathrm{mm} / 12$ hours) of the DF did not differ before or after follicle deviation $(0.50 \pm 0.08$ and $0.60 \pm 0.05$; respectively). Moreover, diameters for DF and largest subordinate follicles at deviation were $6.2 \pm 0.2$ and $5.9 \pm 0.2 \mathrm{~mm}$, respectively, which occurred $2.5 \pm 0.2$ days after ovulation. In another experiment, Gimenes et al. [14] evaluated the size of the dominant follicle to acquire ovulatory capacity in Nelore heifers. Cycling Nelore $(n=13)$, Gir $(\mathrm{n}=11)$, and crossbred Nelore $\times \operatorname{Gir}(\mathrm{n}=10) B$. indicus heifers, at age 24 months and weighing more than $350 \mathrm{~kg}$ had their ovulation synchronized. After ovulation, follicle sizes were determined ultrasonically every 24 hours until diameters of 7.0 to $8.4 \mathrm{~mm}(\mathrm{n}=9), 8.5$ to $10.0 \mathrm{~mm}$ $(n=10)$, or greater than $10.0 \mathrm{~mm}(\mathrm{n}=10)$ were recorded. At these diameters, heifers were submitted to a $25-\mathrm{mg}$ i.m. porcine LH challenge, and then, all heifers were monitored by ultrasonography every 12 hours for 48 hours. Ovulatory capacity was acquired by $33.3 \%$ (3/9) of heifers when the DF was between 7.0 and $8.4 \mathrm{~mm}$ (mean of $7.6 \mathrm{~mm}$ ) in diameter. Thereafter, responsiveness increased significantly after reaching a diameter of $8.5 \mathrm{~mm}(80.0 \% ; 8 / 10)$ but had no additional increase when diameter was larger than $10 \mathrm{~mm}$ (90.0\%; 9/10). In contrast, nonlactating Holstein cows in which the largest growing follicle was $7.0 \mathrm{~mm}(0 / 9)$ or $8.5 \mathrm{~mm}(0 / 9)$ did not ovulate in response to $40 \mathrm{mg}$ of $\mathrm{LH}$. Only when cows had a $10.0-\mathrm{mm}$ follicle, 
ovulation was induced in $80 \%(8 / 10)$ of the cows in response to $\mathrm{LH}[15]$.

\section{Influence of feed intake on reproduction of $B$. taurus versus $B$. indicus cows}

Very few studies have directly evaluated the influence of nutrition on reproductive variables of $B$. taurus versus $B$. indicus. In the following section, we present results of a recent study from our laboratory (unpublished) in which nonlactating Nelore $(\mathrm{n}=12)$ and Holstein $(\mathrm{n}=12)$ cows were submitted to high or low feed intake, in a completely randomized design with a $2 \times 2$ factorial arrangement of treatments. Cows were kept in individual stalls, receiving a maintenance diet according to NRC [3]. After 14 days of adaptation, cows were randomly divided into two groups within breed receiving $70 \%(0.7 \mathrm{M})$ or $180 \%(1.8 \mathrm{M})$ of a maintenance diet in a crossover design. Two weeks after starting feeding experimental diets, estrus was synchronized and the cows were monitored twice a day by ovarian ultrasonography. Blood samples were collected once a day for hormone assays. Independent of diets, Holsteins had less follicles at wave emergence than Nelore cows $(12.7 \pm 5.8$ vs. $31.8 \pm 5.7 \mathrm{AFC})$. Results regarding all variables related to size of ovarian structures were consistent with previous reports, in which Holstein cows had larger ovulatory follicle diameter (14.2 $\pm 0.4 \mathrm{vs} .12 .9 \pm 0.4 \mathrm{~mm})$ and CL volume $\left(5.2 \pm 0.3\right.$ vs. $\left.3.9 \pm 0.3 \mathrm{~cm}^{3}\right)$ than Nelore cows. However, Holstein cows had lesser preovulatory peak of circulating E2 $(12.5 \pm 1.4 \mathrm{vs} .16 .2 \pm 1.3 \mathrm{pg} / \mathrm{mL})$, circulating P4 concentrations ( $1.9 \pm 0.3$ vs. $2.7 \pm 0.3 \mathrm{ng} / \mathrm{mL})$, and circulating insulin concentrations $(2.3 \pm 1.9$ vs. $7.6 \pm 1.8$ $\mu \mathrm{IU} / \mathrm{mL}$ ) on Day 7 of the estrous cycle compared with Nelore cows. Independent of breed, overfed cows (1.8 M) had larger ovulatory follicle diameters (14.6 \pm 0.3 vs. $12.4 \pm 0.3 \mathrm{~mm}$ ) and larger CL volume (5.2 $\pm 0.3 \mathrm{vs}$. $\left.3.9 \pm 0.3 \mathrm{~cm}^{3}\right)$. However, they had lesser circulating preovulatory peak E2 concentrations (12.7 \pm 1.2 vs. $16.0 \pm 1.3 \mathrm{pg} / \mathrm{mL}$ ) and circulating insulin concentrations $(2.6 \pm 1.8$ vs. $7.2 \pm 1.6 \mu \mathrm{IU} / \mathrm{mL})$ on Day 7 of the estrous cycle than those in low feed intake $(0.7 \mathrm{M})$, although circulating
P4 concentrations on Day 7 did not differ $(2.2 \pm 0.2$ vs. $2.4 \pm 0.2 \mathrm{ng} / \mathrm{mL} ; 1.8 \mathrm{M}$ vs. $0.7 \mathrm{M}$, respectively) between diets. Interestingly, regardless of genetic group, overfed cows had follicle deviation occurring later in the cycle ( $2.9 \pm 0.2$ vs. $2.5 \pm 0.2$ days after ovulation), and the diameter, when the largest follicle reached deviation was also greater $(8.1 \pm 0.4 \mathrm{vs}$. $7.4 \pm 0.4 \mathrm{~mm})$ than those under low feed intake. Finally, independent of all the differences observed between breeds, the effect of nutrition on the analyzed variables was very similar between Nelore and Holstein cows (Table 1).

\section{Why are circulating steroids different between $B$. taurus and $B$. indicus?}

Manipulative studies were performed to try to explain why, despite having smaller ovarian structures, $B$. indicus have greater circulating steroid concentrations compared with $B$. taurus heifers or cows. In one $3 \times 3$ Latin square design study [16], the effect of dose of estradiol benzoate (EB; 1,2 , or $4 \mathrm{mg}$ ) associated with P4 on the synchronization of follicular wave emergence was evaluated in nonlactating Nelore $(n=13)$ and Holstein $(n=11)$ cows receiving a maintenance diet [3]. The body condition score and body weight were kept at $3.5 \pm 0.1$ and $3.0 \pm 0.2$ (scale of $1-5)$ and $535 \pm 14$ and $600 \pm 23 \mathrm{~kg}$ for Nelore and Holstein cows, respectively. Two doses of PGF2 $\alpha$ were given 11 days apart, and simultaneously with the second PGF2 $\alpha$, cows were treated with EB and with an intravaginal P4 device, which remained for 10 days. Ovarian dynamics was monitored daily by means of ultrasonography for 10 days after EB treatment. Only cows with follicular wave emergence synchronized by the protocol were included, i.e., when the emergence occurred between 1 and 6 days after treatment with EB + P4. The follicular wave emergence occurred $3.0 \pm 0.3^{\mathrm{a}}, 3.3 \pm 0.1^{\mathrm{ab}}$, and $3.8 \pm 0.2^{\mathrm{b}}$ days after treatment with 1,2 , or $4 \mathrm{mg}$ of $\mathrm{EB}$, respectively ( ${ }^{\mathrm{a}, \mathrm{b}} \mathrm{P} \leq 0.05$ ), independent of breed, although circulating concentrations of E2 24 hours after treatment with EB was much greater in Nelore cows (Fig. 1). The diameter of the largest follicle 9 days after treatment was $12.5 \pm 0.7^{\mathrm{a}}, 11.3 \pm 0.7^{\mathrm{ab}}$, and

Table 1

Ovarian morphology and function and circulating hormones (least squares means \pm standard error) in nonlactating Nelore (Bos indicus) and Holstein (Bos taurus) cows receiving $70 \%$ or $180 \%$ of a maintenance diet $0.7 \mathrm{M}$ or $1.8 \mathrm{M}$, respectively.

\begin{tabular}{|c|c|c|c|c|c|c|c|}
\hline \multirow[t]{3}{*}{ Variable } & \multicolumn{4}{|l|}{ Breed } & \multicolumn{3}{|c|}{ P-value } \\
\hline & \multicolumn{2}{|l|}{ Nelore } & \multicolumn{2}{|l|}{ Holstein } & \multirow[b]{2}{*}{ Breed } & \multirow[b]{2}{*}{ Feed allowance } & \multirow[b]{2}{*}{$\begin{array}{l}\text { Breed } \times \text { feed } \\
\text { allowance }\end{array}$} \\
\hline & $0.7 \mathrm{M}(\mathrm{n}=13)$ & $1.8 \mathrm{M}(\mathrm{n}=14)$ & $0.7 M(n=9)$ & $1.8 \mathrm{M}(\mathrm{n}=14)$ & & & \\
\hline Antral follicle count at wave emergence; $n$ & $36.4 \pm 5.9$ & $27.2 \pm 5.8$ & $12.2 \pm 6.2$ & $13.3 \pm 6.1$ & 0.005 & 0.133 & 0.065 \\
\hline Deviation after ovulation; day & $2.6 \pm 0.3$ & $2.7 \pm 0.3$ & $2.5 \pm 0.3$ & $3.1 \pm 0.3$ & 0.622 & 0.051 & 0.261 \\
\hline Diameter of largest follicle at deviation; mm & $7.1 \pm 0.4$ & $7.4 \pm 0.4$ & $7.6 \pm 0.5$ & $8.8 \pm 0.5$ & 0.020 & 0.025 & 0.160 \\
\hline Diameter of ovulatory follicle; mm & $11.8 \pm 0.4$ & $13.9 \pm 0.4$ & $13.0 \pm 0.4$ & $15.4 \pm 0.4$ & 0.013 & $<0.0001$ & 0.585 \\
\hline Preovulatory circulating estradiol peak; pg/mL & $17.1 \pm 1.6$ & $15.2 \pm 1.5$ & $15.0 \pm 1.7$ & $10.1 \pm 1.6$ & 0.040 & 0.019 & 0.267 \\
\hline Circulating insulin at estrus; $\mu \mathrm{IU} / \mathrm{mL}$ & $6.9 \pm 1.7$ & $10.1 \pm 1.6$ & $3.1 \pm 2.1$ & $3.4 \pm 1.7$ & 0.013 & 0.302 & 0.403 \\
\hline $\begin{array}{l}\text { Volume of corpus luteum on Day } 7 \text { of the } \\
\text { estrous cycle; } \mathrm{cm}^{3}\end{array}$ & $3.3 \pm 0.4$ & $4.4 \pm 0.4$ & $4.6 \pm 0.4$ & $5.8 \pm 0.4$ & 0.007 & 0.012 & 0.930 \\
\hline $\begin{array}{l}\text { Circulating progesterone on Day } 7 \text { of the estrous } \\
\text { cycle; } \mathrm{ng} / \mathrm{mL}\end{array}$ & $3.1 \pm 0.3$ & $2.3 \pm 0.3$ & $1.6 \pm 0.3$ & $2.1 \pm 0.3$ & 0.035 & 0.590 & 0.009 \\
\hline $\begin{array}{l}\text { Circulating insulin on Day } 7 \text { of the estrous cycle; } \\
\mu \mathrm{IU} / \mathrm{mL}\end{array}$ & $3.9 \pm 2.2$ & $11.2 \pm 2.1$ & $1.3 \pm 2.6$ & $3.2 \pm 2.1$ & 0.012 & 0.025 & 0.160 \\
\hline
\end{tabular}




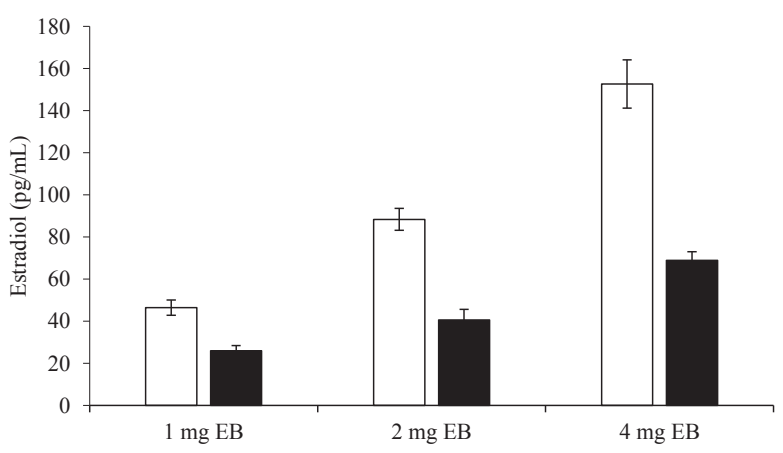

Fig. 1. Circulating estradiol concentrations (LSM \pm SE) 24 hours after treatment with 1,2 , or $4 \mathrm{mg}$ of estradiol benzoate (EB) in nonlactating Holstein $(\mathrm{n}=11 ; \boldsymbol{\square})$ and Nelore $(\mathrm{n}=14 ; \square)$ cows receiving a maintenance diet. There were effects of treatment and breed $(P \leq 0.05)$ [16]. LSM, least squares means; SE, standard error.

$10.4 \pm 0.7^{\mathrm{b}} \mathrm{mm}$ in cows that received 1,2 , or $4 \mathrm{mg}$ of $\mathrm{EB}$, respectively $\left({ }^{\mathrm{a}, \mathrm{b}} \mathrm{P} \leq 0.05\right)$. At follicle wave emergence, the number of 2 to $5 \mathrm{~mm}$ follicles present in the ovaries was greater in Nelore than in Holstein cows $(25.0 \pm 4.4$ vs. $13.2 \pm 2.7$ AFC). Circulating FSH concentrations after $\mathrm{EB}+\mathrm{P} 4$ treatment was greater in Holstein cows (Fig. 2), corroborating other data that have shown an inverse relationship between AFC and FSH [17-19]. Furthermore, follicle deviation occurred, on average, $3.0 \pm 0.2$ days after wave emergence, independent of breed, when the diameter of the largest follicle reached $7.3 \pm 0.4$ and $9.0 \pm 0.5 \mathrm{~mm}$ in Nelore and Holstein cows, respectively. It was concluded that the timing of follicle wave emergence after treatment with $\mathrm{EB}+\mathrm{P} 4$ was EB dose-dependent for both breeds. Moreover, the breed effects observed in this study corroborate previous results and suggests a slower clearance rate of $\mathrm{E} 2$ in B. indicus cows.

Ovulatory follicle size is associated with subsequent $\mathrm{CL}$ size [20] and, therefore, ovulation of smaller follicles results in small CL with reduced ability to increase peripheral concentrations of P4 [21], which is affected by both

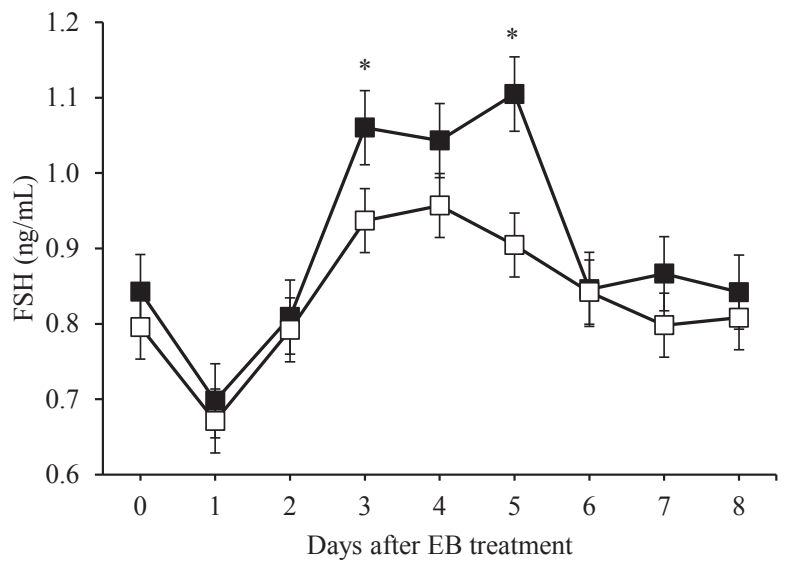

Fig. 2. Circulating FSH concentrations ( $L S M \pm S E$ ) after treatment with 1,2 , or $4 \mathrm{mg}$ of estradiol benzoate (EB) in nonlactating Holstein $(n=11 ; \boldsymbol{\square})$ and Nelore ( $\mathrm{n}=14 ; \square$ ) cows receiving a maintenance diet. There was interaction between breed and day $(\mathrm{P} \leq 0.05)$. Within a day, an asterisk $\left({ }^{*}\right)$ represents effect of breed [2]. LSM, least squares means; SE, standard error. production and inactivation. As mentioned before, differences in CL size are observed between B. taurus and B. indicus breeds. Curiously, although Randel [22] has proposed that $B$. indicus females and crossbreds had lesser P4 concentration per gram of luteal tissue than $B$. taurus and Segerson et al. [23] found no difference in $\mathrm{P} 4$ production by the CL between Brahman and Angus cows, B. indicus have greater circulating concentrations of steroid and metabolic hormones than $B$. taurus cattle. In fact, this greater circulating P4 in B. indicus may not necessarily be exclusively due to greater luteal production because a study with B. indicus (Nelore and Gir), B. taurus (Angus and Holstein), and B. indicus $\times$ B. taurus (Angus $\times$ Nelore and Gir $\times$ Holstein) heifers has detected greater circulating P4 concentrations in $B$. indicus heifers during the time in which they received an intravaginal $\mathrm{P} 4$ releasing device in the absence of a functional CL [5]. Another recent study from our group (unpublished) compared circulating $\mathrm{P} 4$ profile in nonlactating Holstein $(n=20)$, and Nelore $(n=20)$ cows fed a maintenance diet after insertion of an intravaginal implant containing $1.0 \mathrm{~g}$ of P4. Cows did not have a functional CL at the time of implant insertion. There was an effect $(P \leq 0.05)$ of breed (1.2 vs. $2.2 \mathrm{ng} / \mathrm{mL}$, Holstein and Nelore, respectively), in which $\mathrm{P} 4$ concentrations were about $90 \%$ greater in Nelore than in Holstein cows, probably due the greater P4 metabolism in Holsteins (Fig. 3A). After removal of the P4 device, blood was sampled every 40 minutes (0.65 hours) until 240 minutes, and it was seen that the P4 concentration was lesser in Holstein than in Nelore cows (Fig. 3B). Besides, the fractional rate constant of P4 decay $(k)$ [24] was lesser for Nelore than Holstein cows $(0.011 \pm 0.001$ vs. $0.026 \pm 0.007)$, which resulted in a longer half-life of P4 in Nelore cows $(64.9 \pm 6.4$ vs. $26.5 \pm 7.1$ minutes).

It is known that the liver metabolism of steroid hormones is correlated with the dry matter intake [25,26]. However, in our studies, cows were fed the same maintenance diet, and dry matter intake per kg of body weight was $1.37 \%$ for Nelore and $1.54 \%$ for Holstein cows, according to NRC [3] recommendations. There was no body weight gain or loss in any of the studies for both breeds. Therefore, on the basis of these results, we propose that a possible greater steroid metabolism in Holstein cows may be inherent to the breed and not only a consequence of greater feed intake. Moreover, despite contrasting data from previous studies $[22,23]$, we propose that $B$. indicus (mainly represented by the Nelore breed in our studies) have lesser liver steroid metabolism and increased steroid production by the ovaries than $B$. taurus (represented here by the Holstein breed), and that may be associated with greater circulating insulin and IGF1 in B. indicus.

The hypothesis of lesser steroid metabolism in B. indicus due to greater circulating insulin may be supported by other studies. It is known that the greatest amount of circulating $\mathrm{P} 4$ is inactivated or catabolized in hepatocytes by cytochrome P450 2C and cytochrome P450 3A (CYP3A) enzymes. The main metabolites are 21-hydroxyprogesterone and $6 \beta$-hydroxyprogesterone $[27,28]$. Some studies have shown that insulin alters the expression of these enzymes. Studies $[29,30]$, in which hepatocytes of rodents were cultured in vitro, observed a decrease in expression of CYP3A 

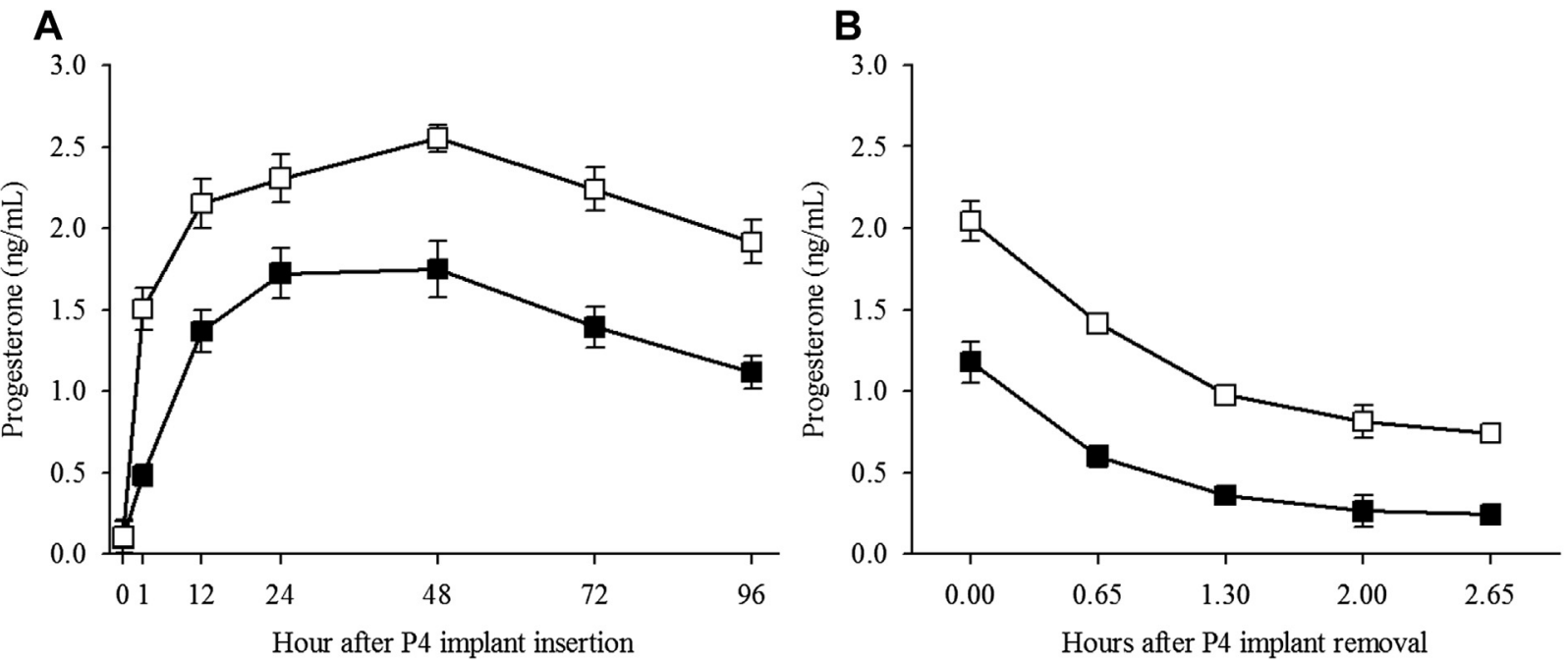

Fig. 3. Circulating progesterone (P4) concentrations (LSM \pm SE) of nonlactating Holstein $(n=20 ; \boldsymbol{\square})$ and Nelore ( $\mathrm{n}=20$; $\square$ ) cows fed with maintenance diet. (A) Blood was sampled before (0 hours), and 1, 6, 12, 24, and 48 hours after P4 implant insertion. There were effects of breed and day (P $\leq 0.05$ ). (B) Blood was sampled immediately before (0 hours) and 0.65, 1.30, 2.00, and 2.65 hours after P4 implant removal. There were effects of breed and day (P $\leq 0.05$; Sartori, 2015; unpublished). LSM, least squares means; SE, standard error.

mRNA when physiological doses of insulin were added to the media. They also observed an insulin dose-dependent decrease in 6 $\beta$-hydroxyprogesterone. Lemley et al. [24] reported that insulin alters the expression of these enzymes in dairy cows. These authors first induced the increase of insulin by propylene glycol infusion and detected lesser expression of CYP3A. Subsequently, insulin and glucose were infused to promote a hyperinsulinemic-euglycemic curve. It was observed that insulin caused a dosedependent decrease in expression of both cytochrome P450 2C and CYP3A enzymes.

Likewise, the hypothesis that $B$. indicus produce more steroid hormones than $B$. taurus due to greater circulating insulin and IGF1 can also be proposed on the basis of data from others. It has been shown that both insulin and IGF1 act as potent stimulators of granulosa cells proliferation and steroidogenesis in cattle [31]. The IGF1 acts in synergism with FSH on steroidogenesis [32] by increasing the P450 aromatase activity [33]. In vitro culture of bovine granulosa cells with $100 \mathrm{ng} / \mathrm{mL}$ of insulin stimulated P450 aromatase mRNA expression and activity and increased E2 secretion by these cells [34]. Bovine granulosa cells were cultured under different concentrations of IGF1 (1, 50, and $100 \mathrm{ng} / \mathrm{mL}$ ) in a serum-free system without insulin [35]. The authors observed that cells cultured with IGF1 (50 or $100 \mathrm{ng} / \mathrm{mL}$ ) had a significant increase in 17 $\beta$-estradiol production, in cell number, in mRNA expression of genes related to steroidogenesis (CYP11A1, HSD3B1, and CYP19A1) and of genes that encode receptors for IGF1 and FSH (FSHR and IGF1R). Cells cultured only with FSH did not have any significant effect. Besides, it was reported that $\mathrm{CL}$ also has IGF1 receptors, and that IGF1 may increase gonadotropin activity and P4 synthesis [36]. Moreover, greater circulating insulin concentrations induced by high feed allowance decreased expression of insulin-like growth factor-binding proteins (IGFBPs), increasing the bioavailability of IGF [37]. It was also cited that nutritional status, i.e., greater circulating insulin, can alter the amount and type of circulating IGFBPs [38]. Lesser circulating IGFBPs, may indicate greater free IGF1 concentration. Finally, it has been shown that, under similar nutrition management conditions, Nelore heifers have approximately 60\% greater circulating cholesterol (precursor for the biosynthesis of steroid hormones) than Holstein heifers (196.8 vs. $123.5 \mathrm{mg} / \mathrm{dL}$ ) [39]. Thus, on the basis of the data presented previously, we must consider that steroid hormone production in the follicles and $\mathrm{CL}$ is, in fact, greater in $B$. indicus than in B. taurus and insulin and IGF1 may be responsible for that. However, to date, there are no reports that have evaluated and directly compared steroid production and metabolism in $B$. taurus versus $B$. indicus females (Fig. 4). Manipulative studies with metabolic hormones within breeds are needed.

\section{In vitro embryo production in $B$. taurus versus B. indicus}

Once several characteristics differ between $B$. taurus and $B$. indicus, the main questions are if these differences could impact reproductive biotechnologies, such as IVEP, and why.

In two recent studies, although with different purposes, B. taurus and B. indicus heifers [9] and cows [8], maintained under the same management and environmental conditions, were submitted to ovum pick-up (OPU)-IVEP and outcomes were compared. In the study by Gimenes et al. [9], Holstein $(n=9)$ and Nelore $(n=9)$ heifers were submitted to six OPU-IVEP replicates (14-day intervals) conducted on different days of pharmacologically synchronized follicle waves. Independent of the day when OPU was performed, Holstein heifers had lesser percentage of viable oocytes/OPU ( $57.7 \pm 2.1$ vs. $68.8 \pm 1.8 \%)$, number of blastocysts/OPU-IVEP $(1.1 \pm 0.2$ vs. $7.3 \pm 0.9)$, blastocyst 


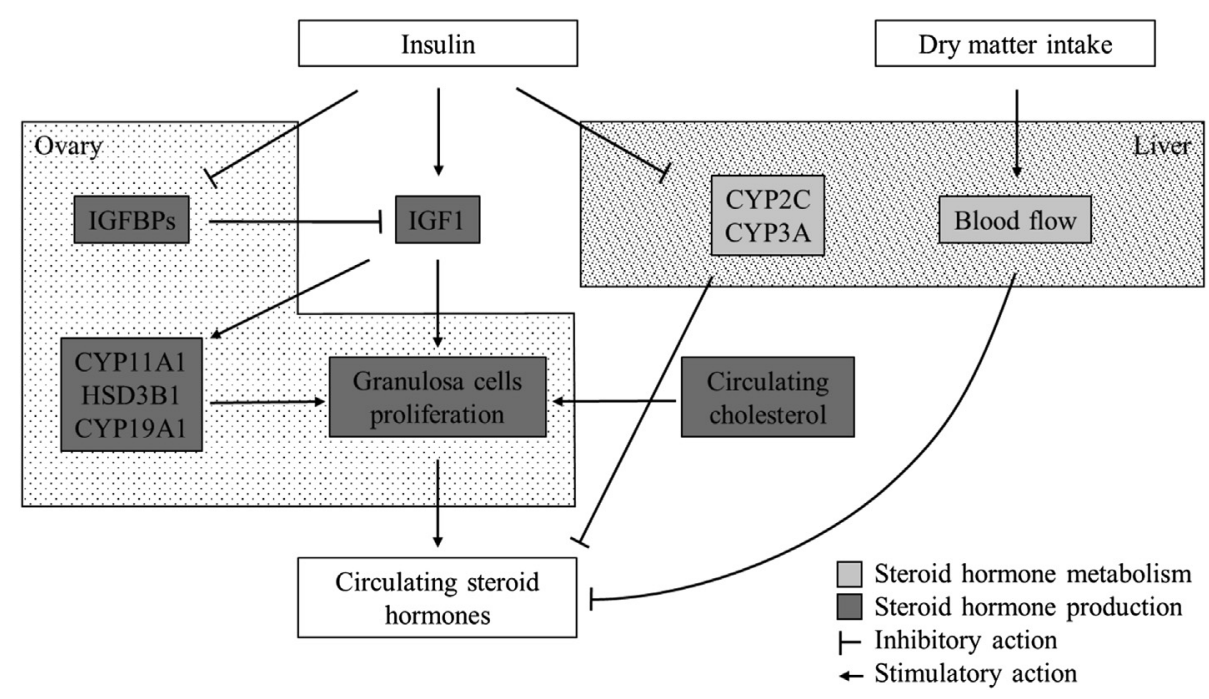

Fig. 4. Schematic illustration of production and metabolism of steroid hormones. Bos indicus have greater circulating insulin than Bos taurus cows or heifers. Insulin stimulates the insulin-like growth factor 1 (IGF1) production directly or indirectly by decreasing the expression of IGFBPs, consequently increasing the bioavailability of IGF1. Within the ovary, IGF1 acts as a potent stimulator of granulosa cell proliferation and steroidogenesis by increasing expression of genes related to steroidogenesis, such as cytochrome P450 A1 (CYP11A1 and CYP19A1) and hydroxy-delta-5-steroid dehydrogenase (HSD3B1). The precursor for the biosynthesis of steroid hormones is cholesterol, and Bos indicus have greater circulating cholesterol than Bos taurus. In addition, insulin decreases expression of cytochrome P450 2C (CYP2C) and cytochrome P450 3A (CYP3A) in hepatocytes, the main enzymes that inactivate or catabolize progesterone. On the other hand, high dry-matter intake increases liver blood flow and, consequently, increases metabolism of steroid hormones.

rates/OPU-IVEP $(14.1 \pm 2.9$ vs. $28.3 \pm 2.8 \%)$, and number of hatched blastocysts/OPU-IVEP $(0.4 \pm 0.1 \mathrm{vs} .3 .7 \pm 0.5)$ than Nelore heifers, respectively. In the study by Sales et al. [8], nonlactating Holstein $(\mathrm{n}=14)$ and Gir $(\mathrm{n}=14)$ cows fed with maintenance (M), or 70\% above maintenance $(1.7 \mathrm{M})$ diets were submitted to nine OPU-IVEP replicates (14-day intervals). Independent of diet, Holstein cows had lesser number of recovered oocytes/OPU (14.6 \pm 0.9 vs. $22.8 \pm 1.5$ ), number of viable oocytes/OPU (10.8 \pm 0.7 vs. $19.3 \pm 1.2$ ), number of blastocysts/OPU-IVEP $(0.7 \pm 0.1$ vs. $3.8 \pm 0.4)$, and blastocyst rates/OPU-IVEP (12.1 vs. $36.7 \%$ ) than Gir cows.

Overall, the main findings of both studies indicate that $B$. taurus yielded less oocytes, as well as produced less blastocysts per OPU-IVEP than $B$. indicus donors. This pattern seems to occur even when other $B$. taurus breeds are studied. Sudano et al. [40] conducted an experiment in which nonlactating Simmental (B. taurus) and Nelore cows were compared for in vivo embryo production and IVEP. Although the total number of recovered ova/embryos per cow (5.5 \pm 0.9 vs. $3.7 \pm 0.8$ ) and transferable embryos per cow ( $3.8 \pm 1.0$ vs. $2.3 \pm 0.8$ ) were not different between Nelore and Simmental, respectively, when IVEP was performed, Nelore produced more oocytes/OPU (14.9 \pm 2.3 vs. $8.1 \pm 1.8)$ and had greater blastocyst rates/OPU-IVEP $(41.5 \pm 1.9$ vs. $23.4 \pm 1.9 \%)$ than Simmental cows. All these IVEP results corroborate commercial data published previously $[41,42]$. According to Pontes et al. [41], Gir cows produced more total oocytes/OPU $(17.1 \pm 4.5$ vs. $11.4 \pm 3.9)$, viable oocytes/OPU ( $12.1 \pm 3.9$ vs. $8.0 \pm 2.7)$, and embryos/ OPU-IVEP (3.2 [12,243/3778] vs. 2.1 [2426/1138]) than Holstein cows. Similarly, on the basis of data collected from four commercial laboratories in Brazil, Viana et al. [42] reported greater embryo production rates of $B$. indicus in comparison to B. taurus cattle (32.1\% [245,123 embryos/ 763,344 oocytes] vs. 25.6\% [2098 embryos/8200 oocytes]).

There is no doubt that the greater AFC in B. indicus can directly affect the better outcomes on OPU-IVEP when compared to $B$. taurus. However, some studies reported lesser DNA fragmentation rate in B. indicus than in B. taurus embryos (16.6 vs. 40.6\% [8]) and indicate that the better blastocyst rates always obtained in B. indicus cows or heifers could be attributed to an intrinsically better quality oocyte [42].

\section{Influence of dry matter or energy intake associated with high insulin on yield and quality of embryos}

Most researchers, who have studied the effect of feed intake on embryo production of B. taurus cows or heifers, reported negative results on the reproductive function of overfed cattle compared with those fed restricted diets (see details in Sartori et al. $[43,44])$. The causes of impaired embryo production related to feed intake are still not well understood. However, changes in liver blood flow, in local and circulating metabolites (glucose and IGF1), in hormone concentrations (insulin and steroids), and in different sources of volatile fatty acids may be involved in these processes. Moreover, we hypothesized that the effects of dietary intake on embryo quality may differ between $B$. taurus and $B$. indicus, which consistently show different concentrations of circulating insulin and IGF1. As discussed in the following section, it is tempting to speculate that $B$. indicus may be more resistant than $B$. taurus breeds to the effects of changes in feed intake on embryo production and quality.

Changes in dry matter intake (DMI) may affect blood concentrations of steroid hormones, IGF1, and insulin and 
affect oocyte quality, fertilization or embryo/oocyte transport, and early embryonic development [45-48], resulting in reduced fertility. In addition to the effects of IGF1 and insulin on steroidogenesis [49-51] and the sensitivity of the follicle to gonadotropic hormones [31], hyperinsulinemia and increased circulating and intrafollicular IGF1 concentrations impair oocyte quality and subsequent embryo development of $B$. taurus [37,52]. In our studies, we investigated how the DMI or energy intake affects in vivo embryo production and IVEP in Nelore cattle.

In the study by Mollo et al. [53], after feeding treatment diets (overfed [170\% of maintenance; $1.7 \mathrm{M}$ ] or restricted [70\% of maintenance; $0.7 \mathrm{M}$ ]) for 9 weeks, overfed Nelore heifers $(n=20)$ had lesser superstimulatory ( $24.0 \pm 1.1$ vs. $48.4 \pm 1.6$ follicles $\geq 6 \mathrm{~mm}$ ) and superovulatory (15.7 \pm 0.9 vs. $33.6 \pm 1.4 \mathrm{CL}$ ) responses in comparison to those in restricted diet $(n=19)$. Moreover, the numbers of recovered embryos/ova (6.7 \pm 0.9 vs. $10.5 \pm 0.6)$ and transferable embryos ( $3.8 \pm 0.4$ vs. $5.7 \pm 0.6)$ were also lesser for the high feed intake heifers. In the same study, the superstimulatory and superovulatory responses and the number of total and transferable embryos seemed to be compromised by greater circulating insulin concentrations measured at the time of the first FSH treatment $(14.3 \pm 1.7$ vs. $3.0 \pm 0.8 \mu \mathrm{IU} / \mathrm{mL} ; 1.7 \mathrm{M}$ and $0.7 \mathrm{M}$, respectively). Regardless of treatment, there was a negative correlation $(-0.61 ; \mathrm{P} \leq 0.05)$ between circulating insulin and the difference in the number of follicles in the ovaries between the last and first day of FSH treatment. However, it is important to note that the percentage of transferable embryos in relation to the total number of ova/embryos collected did not differ between $1.7 \mathrm{M}$ and $0.7 \mathrm{M}$ (65.2 vs. $58.2 \%)$ treatments. Therefore, we speculate that although hyperinsulinemia did not compromise embryo quality, it produced a lesser ovarian sensitivity to FSH in this study.

Bastos et al. [54] did not detect any effect on the superovulatory response, embryo production, or embryo quality in Nelore heifers $(\mathrm{n}=36)$ with greater or lesser body condition score that were fed maintenance $(\mathrm{M})$ or flushing (1.8 M) diets for 14 days before the superovulation treatment.

In the study of Surjus et al. [55], little variation of the superstimulatory response $\left(14.6 \pm 1.6^{\mathrm{a}}\right.$ vs. $12.6 \pm 1.4^{\mathrm{b}}$ vs $13.6 \pm 1.5^{\mathrm{ab}}$ follicles $\left.>6 \mathrm{~mm} ;{ }^{\mathrm{a}, \mathrm{b}} \mathrm{P} \leq 0.05\right)$ was reported in nonlactating Nelore cows $(\mathrm{n}=32)$ at $\mathrm{M}, 0.7 \mathrm{M}$, or $1.5 \mathrm{M}$, respectively, after 42 days of feeding in a Latin square design study. There were no differences in the superovulatory response $(11.0 \pm 1.4$ vs. $9.8 \pm 1.3$ vs. $10.2 \pm 1.3 \mathrm{CL})$, fertilization rate or percentage of viable embryos among experimental groups. Regardless of treatment, circulating insulin at the beginning of superovulation was negatively correlated with the superovulatory response $(r=-0.32)$ and the number of viable embryos $(r=-0.22)$. Pregnancy rates at 23 and 53 days after embryo transfer did not differ between treatments. However, the circulating concentrations of insulin in donors had a low but significant negative correlation with pregnancy of recipients at 60 days of gestation $(\mathrm{r}=-0.16)$.

Guardieiro et al. [56] supplied concentrate with or without rumen-protected fat (Megalac-E, Elanco Animal Health, São Paulo, Brazil), rich in linoleic acid, to 40 Nelore heifers, starting 50 days before superovulation in a crossover experimental design. Supplemental diets were isocaloric and isonitrogenous. The embryos recovered were cryopreserved and subsequently evaluated for in vitro embryo development. The superstimulatory response, number of total embryos/ova, viable embryos, degenerate embryos, or unfertilized oocytes recovered were similar between groups. However, there was negative effect of unsaturated fatty acids on the superovulatory response (15.7 \pm 1.2 vs. $18.0 \pm 1.3 \mathrm{CL}$ ), hatching rate at 48 hours (17.3 $\pm 3.3 \% ; n=137$ vs. $33.1 \pm 4.0 \% ; n=148)$, and at 72 hours ( $30.9 \pm 4.0 \%$; $n=137$ vs. $44.3 \pm 4.2 \% ; n=148$ ) of in vitro culture after thawing. This negative effect associated with a rumen bypass fat diet may have been influenced by lesser circulating concentrations of IGF1 observed in this experimental group compared to control (374.3 \pm 27.2 vs. $483.8 \pm 26.5 \mathrm{ng} / \mathrm{mL}$, respectively).

Our group also performed two studies to investigate the effects of feed intake on IVEP [57,58]. At the first study [57], overfed Nelore cows ( $1.7 \mathrm{M} ; \mathrm{n}=10)$ in comparison to those underfed $(0.7 \mathrm{M} ; \mathrm{n}=10)$ had a small but significant increase in number of follicles $3 \mathrm{~mm}$ or above in diameter at the time of OPU, and associated with this effect was a greater circulating concentration of insulin in the $1.7 \mathrm{M}$ group ( $5.6 \pm 0.8$ vs. $3.5 \pm 0.7 \mu \mathrm{IU} / \mathrm{mL}$ ). Moreover, the diet with greater energy content slightly reduced the percentage of viable oocytes (44.0\%; $n=732$ vs. $48.6 \%$; $n=623$ ). However, there was no difference in the percentage of cleaved oocytes (52.8 vs. $54.8 \%$ ) and blastocyst rate (23.7 vs. $28.2 \%$ ) between $1.7 \mathrm{M}$ and $0.7 \mathrm{M}$, respectively. The other study [58] used the same design as described by Surjus et al. [55]. However, cows underwent OPU 30 days after dietary treatments were started. More recovered oocytes $\left(23.0 \pm 2.3^{\mathrm{a}}\right.$ vs. $20.2 \pm 2.0^{\mathrm{b}}$ vs. $21.5 \pm 2.2^{\mathrm{ab}} ; 0.7 \mathrm{M}, \mathrm{M}$, and $1.5 \mathrm{M}$, respectively) and viable oocytes/OPU (17.0 $\pm 1.9^{\mathrm{a}}$ vs. $14.4 \pm 1.6^{\mathrm{b}}$ vs. $15.7 \pm 1.7^{\mathrm{ab}}$ ) were detected in the $0.7 \mathrm{M}$ diet in relation to the $\mathrm{M}$ diet. Interestingly, cows receiving the 1.5 $\mathrm{M}$ diet did not differ from the other groups. Although the number of cleaved oocytes/OPU was also greater in $0.7 \mathrm{M}$ cows as compared to $\mathrm{M}$ cows (13.4 $\pm 1,7^{\mathrm{a}}$ vs. $10.7 \pm 1.4^{\mathrm{b}}$ vs. $12.6 \pm 1.6^{\mathrm{ab}} ; 0.7 \mathrm{M}, \mathrm{M}$, and $1.5 \mathrm{M}$, respectively), this study did not detect influence of diet on the number ( $6.9 \pm 0.9$ vs. $5.4 \pm 0.8$ vs. $5.9 \pm 0.8$ ) or percentage of blastocysts produced in vitro (30.6 vs. 31.9 vs. $31.1 \%$ ). Moreover, regardless of treatment, cows with lesser circulating insulin concentration $(3.1 \pm 0.8 \mu \mathrm{IU} / \mathrm{mL})$ had similar results as compared to cows with greater circulating insulin $(9.7 \pm 0.2 \mu \mathrm{IU} / \mathrm{mL})$ for all of the variables analyzed, such as blastocyst rate (24.6 vs. $25.9 \%$ ) and pregnancy per embryo transfer (31.2\% [69/221] vs. 33.3\% [71/213]) at 30 days. A recent study [8], however, has shown that nonlactating Gir cows in which $1.7 \mathrm{M}$ diet was offered for more than 60 days had a decrease in blastocyst rate over time (46.9 vs. $25.7 \%$ ). Nevertheless, in the same study, blastocyst rate was the same in nonlactating Holstein cows before or after being overfed for more than 60 days (6.5 vs. 9.8\%).

\section{Concluding remarks}

Metabolic hormones are key elements to the reproductive performance, once they affect different aspects of 
the physiology of the cow. The IGF system, as well as insulin, associated with reproductive hormones, interact with ovarian activity from the initial stages of follicle growth to the process of selection of the DF, as well as final development and ovulation. Curiously, regardless of diet, data suggest that breeds have different production and clearance rates of steroid hormones, in which $B$. taurus may have lesser production and greater metabolism than $B$. indicus breeds. In fact, steroid hormone concentrations are greater in $B$. indicus than in $B$. taurus, whereas ovarian structures are smaller. We suggest metabolic hormones might be implicated in these phenomena.

When considering the effects of high DMI/energy intake on bovine fertility, the negative effects are highlighted because they are associated with a high metabolism of steroid hormones and with an increase in circulating insulin and IGF1 concentrations, potentially compromising oocyte or embryo quality and lowering conception rates. Interestingly, although controversial, negative effects of hyperinsulinemia seem to be more pronounced in embryos produced in vivo than in vitro. Thus, we may speculate that in small follicles ( $<7 \mathrm{~mm}$ ), this impairment on oocyte quality caused by greater circulating insulin and IGF1 concentrations is less intense, especially in B. indicus cattle. In contrast, low circulating IGF1 may compromise follicle number and development as well as embryo production and cryotolerance. Differences in ovarian function related or not to nutrition between $B$. taurus and $B$. indicus breeds are very consistent among studies and may be related to the influence of metabolic hormones such as insulin and IGF1.

\section{Acknowledgments}

Most of the projects presented in this manuscript were funded by grants from FAPESP, CAPES, and CNPq of Brazil. The authors also thank all the students and colleagues that helped with the experiments.

\section{References}

[1] Alvarez P, Spicer LJ, Chase CC, Payton ME, Hamilton TD, Stewart RE, et al. Ovarian and endocrine characteristics during an estrous cycle in Angus, Brahman, and Senepol cows in a subtropical environment. J Anim Sci 2000;78:1291-302.

[2] Bastos MR, Mattos MCC, Meschiatti MAP, Surjus RS, Guardieiro MM, Ferreira JCP, et al. Ovarian function and circulating hormones in nonlactating Nelore versus Holstein cows. Acta Sci Vet 2010; 38(Suppl. 2):776 (abstract).

[3] NRC. Nutrient Requirements of Dairy Cattle. Seventh rev. edition 2001. Washington: DC.

[4] Baldrighi JM, Sa Filho MF, Batista EOS, Lopes RNVR, Visintin JA Baruselli PS, et al. Anti-Mullerian hormone concentration and antral ovarian follicle population in Murrah heifers compared to Holstein and Gyr kept under the same management. Reprod Domest Anim 2014;49:1015-20.

[5] Carvalho JBP, Carvalho NAT, Reis EL, Nichi M, Souza AH, Baruselli PS, Effect of early luteolysis in progesterone-based AI protocols in Bos indicus, Bos indicus $\mathrm{x}$ Bos taurus and Bos taurus heifers. Theriogenology 2008;69:167-75.

[6] Mattos MCC, Bastos MR, Guardieiro MM, Carvalho JO, Franco MM, Mourao GB, et al. Improvement of embryo production by the replacement of the last two doses of porcine follicle-stimulating hormone with equine chorionic gonadotropin in Sindhi donors. Anim Reprod Sci 2011;125:119-23.

[7] Batista EOS, Macedo GG, Sala RV, Ortolan MDDV, Sa Filho MF, Del Valle TA, et al. Plasma antimullerian hormone as a predictor of ovarian antral follicular population in Bos indicus (Nelore) and Bos taurus (Holstein) heifers. Reprod Domest Anim 2014;49:448-52.

[8] Sales JNS, Iguma LT, Batista RITP, Quintao CCR, Gama MAS, Freitas C, et al. Effects of a high-energy diet on oocyte quality and in vitro embryo production in Bos indicus and Bos taurus cows. J Dairy Sci 2015;98:3086-99.

[9] Gimenes LU, Ferraz ML, Fantinato-Neto P, Chiaratti MR, Mesquita LG, Sa Filho MF, et al. The interval between the emergence of pharmacologically synchronized ovarian follicular waves and ovum pickup does not significantly affect in vitro embryo production in Bos indicus, Bos taurus, and Bubalus bubalis. Theriogenology 2015;83:385-93.

[10] Sartori R, Guardieiro MM, Surjus RS, Melo LF, Prata AB, Ishiguro M, et al. Metabolic hormones and reproductive function in cattle. Anim Reprod 2013;10:199-205.

[11] Austin EJ, Mihm M, Evans ACO, Knight PG, Ireland JLH, Ireland JJ, et al. Alterations in intrafollicular regulatory factors and apoptosis during selection of follicles in the first follicular wave of the bovine estrous cycle. Biol Reprod 2001;64:839-48.

[12] Sartori R, Bastos MR, Baruselli PS, Gimenes LU, Ereno RL, Barros CM. Physiological differences and implications to reproductive management of Bos taurus and Bos indicus cattle in a tropical environment. In: Lucy MC, Pate JL, Smith MF, Spencer TE, editors. Reproduction in domestic ruminants. Nottingham: Nottingham University Press; 2010. p. 357-75.

[13] Sartori R, Barros CM. Reproductive cycles in Bos indicus cattle. Anim Reprod Sci 2011;124:244-50.

[14] Gimenes LU, Sa MF, Carvalho NAT, Torres JRS, Souza AH, Madureira EH, et al. Follicle deviation and ovulatory capacity in Bos indicus heifers. Theriogenology 2008;69:852-8.

[15] Sartori R, Fricke PM, Ferreira JCP, Ginther OJ, Wiltbank MC. Follicular deviation and acquisition of ovulatory capacity in bovine follicles. Biol Reprod 2001;65:1403-9.

[16] Bastos MR, Surjus RS, Prata AB, Meschiatti MAP, Borsato M, Mourão GB, et al. Dose effect of estradiol benzoate associated with progesterone on the synchronization of follicular wave emergence in Bos indicus and Bos taurus cows. Acta Sci Vet 2011;39(Suppl. 1): 315 (abstract).

[17] Haughian JM, Ginther OJ, Kot K, Wiltbank MC. Relationships between FSH patterns and follicular dynamics and the temporal associations among hormones in natural and GnRHinduced gonadotropin surges in heifers. Reproduction 2004; 127:23-33.

[18] Ireland JJ, Ward F, Jimenez-Krassel F, Ireland JLH, Smith GW, Lonergan $\mathrm{P}$, et al. Follicle numbers are highly repeatable within individual animals but are inversely correlated with FSH concentrations and the proportion of good-quality embryos after ovarian stimulation in cattle. Hum Reprod 2007;22:1687-95.

[19] Ireland JJ, Smith GW, Scheetz D, Jimenez-Krassel F, Folger JK, Ireland JLH, et al. Does size matter in females? An overview of the impact of the high variation in the ovarian reserve on ovarian function and fertility, utility of anti-Mullerian hormone as a diagnostic marker for fertility and causes of variation in the ovarian reserve in cattle. Reprod Fertil Dev 2011;23:1-14.

[20] Sartori R, Rosa GJM, Wiltbank MC. Ovarian structures and circulating steroids in heifers and lactating cows in summer and lactating and dry cows in winter. J Dairy Sci 2002;85:2813-22.

[21] Vasconcelos JLM, Sartori R, Oliveira HN, Guenther JG, Wiltbank MC. Reduction in size of the ovulatory follicle reduces subsequent luteal size and pregnancy rate. Theriogenology 2001;56:307-14.

[22] Randel RD. LH and ovulation in Brahman, Brahman x Hereford and Hereford heifers. J Anim Sci 1976;43:300-1.

[23] Segerson EC, Hansen TR, Libby DW, Randel RD, Getz WR. Ovarian and uterine morphology and function in Angus and Brahman cows. J Anim Sci 1984;59:1026-46.

[24] Lemley CO, Koch JM, Blemings KP, Krause KM, Wilson ME. Concomitant changes in progesterone catabolic enzymes, cytochrome P450 2C and 3A, with plasma insulin concentrations in ewes supplemented with sodium acetate or sodium propionate. Animal 2008;2:1223-9.

[25] Sangsritavong S, Combs DK, Sartori R, Armentano LE, Wiltbank MC. High feed intake increases liver blood flow and metabolism of progesterone and estradiol-17 beta in dairy cattle. J Dairy Sci 2002;85: 2831-42.

[26] Vasconcelos JLM, Sangsritavong S, Tsai SJ, Wiltbank MC. Acute reduction in serum progesterone concentrations after feed intake in dairy cows. Theriogenology 2003;60:795-807.

[27] Murray M. Microsomal cytochrome-P450-dependent steroidmetabolism in male sheep liver - quantitative importance of 
6-beta-hydroxylation and evidence for the involvement of a P450 from the IIIa subfamily in the pathway. J Steroid Biochem Mol Biol 1991;38:611-9.

[28] Murray M. Participation of a cytochrome P450 enzyme from the 2C subfamily in progesterone 21-hydroxylation in sheep liver. J Steroid Biochem Mol Biol 1992;43:591-3.

[29] Sidhu JS, Omiecinski CJ. Insulin-mediated modulation of cytochrome p450 gene induction profiles in primary rat hepatocyte cultures. J Biochem Mol Toxicol 1999;13:1-9.

[30] Saad B, Thomas H, Schawalder H, Waechter F, Maier P. Oxygentension, insulin, and glucagon affect the preservation and induction of cytochrome-P450 isoforms in cultured rat hepatocytes. Toxicol Appl Pharmacol 1994;126:372-9.

[31] Webb R, Garnsworthy PC, Gong JG, Armstrong DG. Control of follicular growth: local interactions and nutritional influences. J Anim Sci 2004;82:63-74.

[32] Lucy MC. Regulation of ovarian follicular growth by somatotropin and insulin-like growth factors in cattle. J Dairy Sci 2000;83: 1635-47.

[33] Echternkamp SE, Howard HJ, Roberts AJ, Grizzle J, Wise T. Relationships among concentrations of steroids, insulin-like growthfactor-I, and insulin-like growth-factor binding-proteins in ovarian follicular-fluid of beef-cattle. Biol Reprod 1994;51:971-81.

[34] Silva JM, Price CA. Insulin and IGF-I are necessary for FSH-induced cytochrome P450 aromatase but not cytochrome P450 side-chain cleavage gene expression in oestrogenic bovine granulosa cells in vitro. J Endocrinol 2002;174:499-507.

[35] Mani AM, Fenwick MA, Cheng Z, Sharma MK, Singh D, Wathes DC. IGF1 induces up-regulation of steroidogenic and apoptotic regulatory genes via activation of phosphatidylinositol-dependent kinase/ AKT in bovine granulosa cells. Reproduction 2010;139:139-51.

[36] Santos JEP, Cerri RLA, Sartori R. Nutritional management of the donor cow. Theriogenology 2008;69:88-97.

[37] Armstrong DG, McEvoy TG, Baxter G, Robinson JJ, Hogg CO, Woad KJ, et al. Effect of dietary energy and protein on bovine follicular dynamics and embryo production in vitro: associations with the ovarian insulin-like growth factor system. Biol Reprod 2001;64:1624-32.

[38] Gong JG, Armstrong DG, Baxter G, Hogg CO, Garnsworthy PC, Webb R. The effect of increased dietary intake on superovulatory response to FSH in heifers. Theriogenology 2002;57: $1591-602$.

[39] Gandra JR, Freitas JE, Barletta RV, Maturana M, Gimenes LU, Vilela FG, et al. Productive performance, nutrient digestion and metabolism of Holstein (Bos taurus) and Nellore (Bos taurus indicus) cattle and Mediterranean buffaloes (Bubalis bubalis) fed with corn-silage based diets. Livest Sci 2011;140:283-91.

[40] Sudano MJ, Caixeta ES, Paschoal DM, Martins Jr A, Machado R, Buratini J, et al. Cryotolerance and global gene-expression patterns of Bos taurus indicus and Bos taurus taurus in vitro- and in vivoproduced blastocysts. Reprod Fertil Dev 2014;26:1129-41.

[41] Pontes JHF, Silva KCF, Basso AC, Rigo AG, Ferreira CR, Santos GMG, et al. Large-scale in vitro embryo production and pregnancy rates from Bos taurus, Bos indicus, and indicus-taurus dairy cows using sexed sperm. Theriogenology 2010;74:1349-55.

[42] Viana JHM, Siqueira LGB, Palhao MP, Camargo LSA. Features and perspectives of the Brazilian in vitro embryo industry. Anim Reprod 2012;9:12-8.
[43] Sartori R, Guardieiro MM, Surjus R. Effects of dry matter or energy intake on embryo quality in cattle. Cattle Pract 2013;21:50-5.

[44] Sartori R, Guardieiro MM, Mollo MR, Surjus RS. Feed intake and reproduction in cattle. In: Garnsworthy PC, Wiseman J, editors. Recent advances in animal nutrition. First edtion. Nottingham: Nottingham University Press; 2012. p. 21-36.

[45] Folman Y, Rosenber M, Herz Z, Davidson M. Relationship between plasma progesterone concentration and conception in postpartum dairy-cows maintained on 2 levels of nutrition. J Reprod Fertil 1973; 34:267-78.

[46] Fonseca FA, Britt JH, McDaniel BT, Wilk JC, Rakes AH. Reproductive traits of Holsteins and Jerseys - effects of age, milk-yield, and clinical abnormalities on involution of cervix and uterus, ovulation, estrous cycles, detection of estrus, conception rate, and days open. J Dairy Sci 1983;66:1128-47.

[47] Mann GE, Lamming GE, Robinson RS, Wathes DC. The regulation of interferon-tau production and uterine hormone receptors during early pregnancy. J Reprod Fertil Suppl 1999;54:317-28.

[48] Inskeep EK. Preovulatory, postovulatory, and postmaternal recognition effects of concentrations of progesterone on embryonic survival in the cow. J Anim Sci 2004;82:24-39.

[49] Gutierrez CG, Campbell BK, Webb R. Development of a long-term bovine granulosa cell culture system: induction and maintenance of estradiol production, response to follicle-stimulating hormone, and morphological characteristics. Biol Reprod 1997;56:608-16.

[50] Armstrong DG, Gong JG, Gardner JO, Baxter G, Hogg CO, Webb R. Steroidogenesis in bovine granulosa cells: the effect of short-term changes in dietary intake. Reproduction 2002;123:371-8.

[51] Gong JG, Lee WJ, Garnsworthy PC, Webb R. Effect of dietary-induced increases in circulating insulin concentrations during the early postpartum period on reproductive function in dairy cows. Reproduction 2002;123:419-27.

[52] Adamiak SJ, Mackie K, Watt RG, Webb R, Sinclair KD. Impact of nutrition on oocyte quality: cumulative effects of body composition and diet leading to hyperinsulinemia in cattle. Biol Reprod 2005;73: 918-26.

[53] Mollo MR, Rumpf R, Martins AC, Mattos MCC, Lopes Jr G, Carrijo IHD, et al. Ovarian function in Nelore heifers under low or high feed intake. Acta Sci Vet 2007;35(Suppl. 3):958 (abstract).

[54] Bastos MR, Martins AC, Melo LF, Carrijo LHD, Rumpf R, Sartori R. Effect of body condition score and feed intake on the superovulatory response and embryo production in Nelore heifers. Acta Sci Vet 2007;35(Suppl. 3):1242 (abstract).

[55] Surjus RS, Prata AB, Borsato M, Martins da Silveira MC, Mattos MCC, Mattos FCSZ, et al. Influence of high or low intake of dry matter and energy on in vivo production of bovine embryos. Reprod Fertil Dev 2012;24:227, abstract.

[56] Guardieiro MM, Machado GM, Bastos MR, Mourao GB, Carrijo LHD, Dode MAN, et al. A diet enriched in linoleic acid compromises the cryotolerance of embryos from superovulated beef heifers. Reprod Fertil Dev 2014;26:511-20.

[57] Martins AC, Ramos AF, Mollo MR, Pivato I, Camara JU, Carrijo LHD, et al. Influence of high or low feed intake on in vitro embryo production in cattle. Acta Sci Vet 2006;34(Suppl. 1):290. abstract.

[58] Prata AB, Surjus RS, Borsato M, Martins Da Silveira MC, Mattos MCC, Santos FAP, et al. Influence of high or low intake of dry matter/ energy on in vitro production of bovine embryos. Acta Sci Vet 2011; 39(Suppl. 1):332 (abstract). 